\title{
Contributing to the Development of Grand Challenges in Maths Education
}

\author{
David Barnes, Trena Wilkerson and Michelle Stephan
}

David Hilbert (1902) presented a set of challenging problems before the International Conference of Mathematics and argued that mathematics was at a crossroads and a sense of direction was necessary to guide the field forward in the next century. He submitted a list of mathematics problems that had yet been solved and some questions that had not even been asked to spark creativity and discovery. He also understood the importance of a community of scholars being able to determine when a problem is solved, the need to develop new representations to express a problem, and the ability to explain its solution.

As others have undertaken defining Grand Challenges, Gould (2010), the following represent some guidelines:

1. Define complex and difficult questions that are solvable within a 10-20 year timeframe;

2. Positively impact the quality of life for potentially millions through educational, social, and economic outcomes;

3. Require multiple sub-disciplines to engage/collaborate on research;

4. Have a defined, measureable outcome to gauge progress and completion; and

5. Garner support publicly and within the field which understand, and appreciate the outcomes of the effort.

The Research Committee (Stephan et al., 2015) introduced the concept of Grand Challenges to our mathematics education research community. While there are significant differences in the local and national challenges when you consider

D. Barnes $(\bowtie)$

Research, Learning and Development, National Council of Teachers of Mathematics,

Reston, USA

e-mail: dbarnes@nctm.org

(C) The Author(s) 2017

G. Kaiser (ed.), Proceedings of the 13th International Congress on Mathematical

Education, ICME-13 Monographs, DOI 10.1007/978-3-319-62597-3_114 
mathematics education globally, there are also likely to be significant overlap. The endeavor of ICME is founded on the desire to "promote the collaboration, exchange and dissemination of ideas and information on all aspects of the theory and practice of contemporary mathematical education." The voluntary participation in and adoption of a common set of Grand Challenges in Maths Education works to support the international collaboration toward common challenges.

The following key questions were discussed:

- As you consider the state of maths education in your community/country what would you see as research questions that could qualify as grand challenges?

- Which of a preliminary set of additional questions would be of interest to the maths education and research community for your country? What are the benefits and what are the risks?

- Are there opportunities to engage educators, researchers and policy makers in the development of Grand Challenges in Maths Education and collaborative efforts to solve these problems?

Small group discussion surfaced the universal nature of some challenges and the real and regional nature of other challenges. Consistent challenges include the access to education for all individuals no matter gender or status.

\section{References}

Gould, M. (2010). GIScience grand challenges: How can research and technology in this field address big-picture problems? ArcUser, 13(4), 64-65. Retrieved from http://www.esri.com/ news/arcuser/1010/files/geochallenges.pdf

Hilbert, D. (1902). Mathematical problems. Bulletin of the American Mathematical Society, 8(10), 437-479. doi:10.1090/S0002-9904-1902-00923-3

Stephan, M. L., Chval, K. B., Wanko, J. J., Civil, M., Fish, M., Herbel-Eisenmann, B., Konold, C., \& Wilkerson, T.L. (2015). Grand challenges and opportunities in Mathematics Education Research. Journal for Research in Mathematics Education, 46(2), 134-146. Retrieved from http://bit.ly/1Yd4q2V

Open Access Except where otherwise noted, this chapter is licensed under a Creative Commons Attribution 4.0 International License. To view a copy of this license, visit http://creativecommons. org/licenses/by/4.0/.

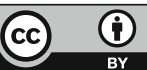

